\title{
Beyond Seablindness: A New Agenda for Maritime Security Studies
}

\author{
Christian Bueger, Timothy Edmunds
}

\begin{abstract}
This article examines the rise of maritime security in concept and practice. We argue that developments in the maritime arena have flown beneath the radar of much mainstream international relations and security studies scholarship, and that a new agenda for maritime security studies is required. In this article we outline the contours of such an agenda, with the intention of providing orientation and direction for future research. Our discussion is structured into three main sections, each of which outlines a core dimension of the maritime security problem space. We begin with a discussion of the issues and themes that comprise the maritime security agenda, including how it has been theorized in security studies to date. Our argument is that the marine environment needs to be understood as part of an interlinked security complex, which also incorporates strong connections between land and sea. Second, we examine the ways in which maritime security actors have responded to these challenges in practice, focusing on issues of maritime domain awareness, coordination of action, and operations in the field. Third, we turn to the mechanisms through which the new maritime security agenda is being disseminated to local actors through a process of devolved security governance. We focus particularly on efforts to distribute knowledge and skills to local actors through capacity building and security sector reform. In the conclusion, we outline the future challenges for maritime security studies that follow from these observations.
\end{abstract}

Keywords: Maritime Security, Marine Environment Safety, Piracy, Maritime Blindness.

Maritime security is one of the latest additions to the vocabulary of international security. Initially coined in the 1990s, the concept has received growing attention due to the intensification of concerns over maritime terrorism since 2000, the rise of modern piracy off the coast of Somalia and elsewhere, maritime crimes such as human trafficking, and the increasing significance in recent years of the so-called "blue economy' and issues relating to maritime environmental protection and resource management. 


\section{Introduction}

A significant number of states and other international actors place maritime security high on their security agendas. This priority is reflected in several governmental and intergovernmental strategies for maritime security published in the past decade-including those of the United States, United Kingdom, France, India, NATO, the European Union (EU) and the African Union (AU) - as well as in multilateral statements such as the G7 declaration on maritime security, and in the work of the annual international Our Ocean conference on the theme.

If maritime security has become a core concern among major global security actors, the same cannot be said of International Relations (IR) and security studies more widely, where its study is scattered at best. Existing literature tends to consider such issues in terms of particular geographic hot spots and the management of specific threats, such as maritime piracy in east Africa, strategic rivalry in the South China Sea or the Arctic, organized crime in west Africa or human trafficking in the Mediterranean ${ }^{1}$. Issues such as port security, illegal fishing or environmental crime have received less attention, and the connections between all these themes remain underexplored.

Other literatures subordinate developments at sea to wider themes in IR, such as Great Power politics, geostrategy or international regimebuilding2. The rise of the maritime security agenda has been reflected in a renewed interest among maritime scholars in the question of order at sea in an age of globalization ${ }^{3}$, and in its increasing significance in national strategic, policy and doctrinal publications. Less attention has been paid to the maritime arena as a crucible of international change and innovation in and of itself. This is an important oversight, and one that risks obscuring specific and novel patterns of international interaction, governance and political order at sea.

1 Felix K. Chang, "China's naval rise and the South China Sea: an operational assessment”, Orbis, 56, no. 2, (2012): 19-38.

2 Jack S. Levy, and William R. Thompson, "Balancing on land and at sea: do states ally against the leading global power?”, International Security, 35, no. 1, (2010): 7-43.

3 Jo Inge Bekkevold and Geoffrey Till, International order at sea: how it is challenged, how it is maintained, (Basingstoke: Palgrave Macmillan, 2016). 
This article argues that the maritime security initiatives and activities that have been observable throughout the past decade call for a more substantial treatment of the matter in the academic discussion. It is time for the discipline to pay more attention to the maritime arena and move beyond seablindness. The objective of this article is accordingly to summarize some of the core observations that can be made with regard to these developments and activities at sea, and outline the ways in which these require more focused research.

Our goal is twofold: first, to give some order to current developments so as to provide direction and foundations for further maritime security studies; second, to explore the fascinating challenges raised by maritime security phenomena in wider discussions within IR and security studies.

Our discussion is structured in three main sections, each of which outlines a core dimension of maritime security. We begin with a consideration of the issues and themes that comprise the maritime security agenda. These include the manner in which it has been theorized in security studies to date, as well as its growing prominence in security policy thinking and documentation. Second, we examine the ways in which maritime security actors have responded to these challenges in practice, focusing on issues of maritime domain awareness, coordination of action and operations in the field. While we aim at providing a broad overview, many of our examples stem from the western Indian Ocean, in relation to which paradigmatic observations can be made. Third, we turn to the mechanisms through which the new maritime security agenda is being disseminated to local actors through a process of devolved security governance. We focus particularly on efforts to distribute knowledge and skills to local actors through capacity-building and security sector reform (SSR).

In the conclusion, we outline the future challenges for maritime security studies that follow from these observations. We argue that in addition to the traditional concerns of studies of sea power and the legal structures governing the sea, maritime security studies need to pay greater attention to the interconnectivity of different threats and issues, to novel forms of governance and order at sea, and to the dissemination of the new maritime security agenda through capacity-building. 


\section{The Rise of Maritime Security}

Throughout human history the sea has been viewed as a zone of danger and insecurity. As the historian John Mack argues, the seas have recurrently been presented as an unwelcome and unwelcoming wilderness where the land is a reassuring point of reference' 4 . Mack suggests that human history can be read as an attempt to master the sea. Yet, in reviewing the literature, he finds that the vast majority of historical and political analyses portray the seas 'either as the backdrop to the stage on which the real action is seen to take place-that is, landor ... simply as means of connection between activities taking place at coasts and in their interiors'5. His diagnosis also appears accurate for much of the existing discussion in IR and security studies. The sea tends to be understood as the stage for geopolitical power projection, interstate warfare or militarized disputes, as a source of specific threats such as piracy, or as a connector between states that enables various phenomena from colonialism to globalization'.

\section{Theorizing Security at Sea}

In the main, security at sea has been theorized and interpreted from rather conservative viewpoints based in traditional realist or liberalist theory. More recent theoretical developments, such as constructivist thinking or critical security studies, have hardly influenced the debate.

In the realist interpretation, the seas are the plain on which superpower or regional power rivalry takes place. Recent discussions have focused on the rise of China as a naval power and the US Asian 'pivot', the investments in naval capabilities of emerging powers, or resource competition in the Arctic $^{7}$. This research has been driven forward primarily by scholars of sea power. Generally understood as a sub-branch of strategic studies, this field has long been concerned with

4 John, M., The sea: a cultural history. (London: Reaktion, 2011).

5 Ibid

6 Philip, E. Steinberg, The social construction of the ocean. (Cambridge: Cambridge University Press, 2001).

7 Margaret Blunden, "The new problem of Arctic stability," Survival, 25, no. 5, (2009): 121-142. 
questions of international interaction, influence and order at sea ${ }^{8}$. Such work has been located primarily in classical realist and geopolitical frameworks of IR, with an emphasis on historical analysis, the distribution of hard naval power and military competition ${ }^{9}$. In consequence, this scholarship has tended to prioritize what Bekkevold and Till call 'top-down' or structural influences on international order at sea, including 'global power shifts, changing threat perceptions, naval modernization, and changes in naval capabilities and enforcement of the Law of the Sea'10. It has paid less attention to the 'bottom-up' influence of maritime disorder on international order at sea, and the forms of interaction, cooperation and conflict that emerge from such disorder.

Liberal interpretations of security at sea foreground the rise of various international regimes governing activities at sea, and suggest that the marine environment is increasingly subject to a form of collective public order and legal regulation. Liberal perspectives have been advanced in particular in the work of maritime legal scholars ${ }^{11}$. Kraska and Pedrozzo, for instance, suggest that in recent years international law has 'evolved from a set of rules designed to avoid naval warfare by keeping maritime powers apart, toward a new global framework designed to facilitate maritime security cooperation by bringing countries together to reach common goals'12. Even so, such work has tended to focus on issues of technical regulation and formal international law, rather than maritime security governance more widely defined.

Indeed, we concur with Ian Speller that the maintenance of good order at sea has not traditionally been subject to theoretical analysis in

8 Ken Booth, Navies and foreign policy, (London: Croom Helm, 1977).

9 Geoffrey Till, Seapower: A Guide for the Twenty-First Century, (Florida, USA: CRC Press, 2018).

${ }^{10}$ Jo Inge and Geoffrey, International order at sea: how it is challenged, how it is maintained, 2018.

${ }^{11}$ Robin Geib and Anna Petrig, Piracy and robbery at sea: the legal framework for counterpiracy operations in Somalia and the Gulf of Aden, (Oxford: Oxford University Press, 2011).

12 James, Kraska and Raul Pedrozo, International maritime security law, (Leiden: Nijhoff, 2014) 
the same way as wartime activity or even diplomatic roles'13. Certainly, newer security theorizing as it has been developed by constructivists since the 1990s and in critical security studies, for example in the form of securitization theory or the security as practice approach, has, with few exceptions, hardly influenced the debate on security at sea ${ }^{14}$. As we shall elaborate further below, understanding the contemporary maritime security agenda requires that such considerations be incorporated in the analysis.

The concept of maritime security as a distinct subset of security thinking-including but not confined to existing themes of sea power and maritime law -is a relatively recent creation. In many ways, the study of the seas has lagged considerably behind developments in mainstream security studies. The latter discipline's traditional focus on states, armed forces and war has been commonly 'broadened' and 'deepened' to incorporate a much wider set of security issues, domains and activities, since the early 1990s at least. These have included socalled 'new' security issues such as terrorism, transnational organized crime or environmental degradation, affecting a diverse range of actors including but not limited to the state, and have been characterized by multisectoral responses such as the increasing tendency to link security with development ${ }^{15}$.

\section{The Path to Maritime Security}

A short reconstruction of the rise of maritime security emphasizes how important these additional dimensions are. Expanded notions of security began to gain substantive intellectual and policy traction in the maritime sphere around the turn of the millennium. Of particular significance was the 1998 report of the Independent World Commission on the Oceans (IWCO). Published to coincide with the UN's International Year of the Oceans, this considered a range of military and non-military

${ }^{13}$ Ian Speller, Understanding naval warfare, (London: CRC Press, 2014).

14 Barry J. Ryan, “Security spheres: a phenomenology of maritime spatial practices," Security Dialogue, 46, no. 6, (2015): 568-584.

15 Barry Buzan, Ole Waever, and Jaap de Wilde, Security: a new frameworkfor analysis, (London: Lynne Rienner, 1998). 
threats to international order at sea, as well as the manner in which maritime security governance should be reconfigured to address them ${ }^{16}$.

This process gathered further momentum in the wake of the attack on the USS Cole in the port of Aden by an extremist group in 2000 and the attacks of 11 September 2001, after which the United States began to focus significant attention on the maritime dimension of national and homeland security. The US government published a National Strategy for Maritime Security (NSMS) in 2005, accompanied by eight supporting plans to address 'the specific threats and challenges of the maritime environment' ${ }^{17}$. The NSMS was one of the first documents of its kind to explicitly conceive of the maritime sphere as a differentiated security complex in its own right. The strategy placed considerable emphasis on maritime vulnerabilities to terrorism, including the prospect of terrorist attack either at or from sea, and the challenges of securing ports and coastal areas from the incursion of terrorist materials, including potentially weapons of mass destruction (WMD). However, like the IWCO report, it also identified a series of wider maritime security challenges. These included the threat of piracy, the illegal exploitation of maritime resources, smuggling and criminality, and other threats to the free movement of seaborne trade ${ }^{18}$.

The NSMS was followed by a series of developments in US strategy that placed good order at sea at the heart of the country's naval thinking. For example, the '1000 Ship Navy' concept of 2005-2006 began with a recognition that the challenges of maritime security were too complex and diffuse for the United States to handle on its own. Instead, it envisaged what Peter Haynes has called 'a self-organizing, selfgoverning, come-as-you-are cooperative global maritime security network that coordinate[s] the activities of volunteer nations' navies, coastguards and constabulary units' 19 . This notion was controversial at

16 IWCO, The ocean our future (Cambridge: Cambridge University Press, 1998): 17.

17 US Government, The National Strategy for Maritime Security. (2005), https://www.hsdl.org/?view\&did=456414.

18 Ibid

${ }^{19}$ Peter De Haynes, Toward a new maritime strategy: American naval thinking in the postCold War era, (Annapolis, Maryland: Naval Institute Press, 2015) 
the time, and ultimately stymied by suspicion of US motives on the part of some potential partner states and controversy within the US Navy itself. However, it did point to several important future trends, including the difficulties faced by a single state-no matter how powerful-in managing a diffuse and complex maritime security environment, and the need for cooperative relations with others in areas of shared interest. It was also indicative of a broader and more expansive understanding of sea power on the part of the United States. As Admiral Michael Mullen, Chief of Naval Operations for the US Navy, noted in 2006: 'It is time to elevate the discussion of sea power. For far too long and in far too many ways, it has been about big-ship battles and high tech weapons systems. Life is just not that simple anymore ... we face entirely new challenges ${ }^{20}$.

In the wake of US efforts, a number of similar strategies have been adopted by other nations and international organizations. Of these, the most notable are NATO's Alliance Maritime Strategy (2011), the UK National Strategy for Maritime Security (2014), the EU Maritime Security Strategy (also 2014), the French National Strategy for the Security of Maritime Areas (2015) and the G7 Declaration on Maritime Security (also 2015). The AU concluded the negotiations on its 2050 Africa's Integrated Maritime (AIM) Strategy in 2014, following up with a Charter on Maritime Security, Safety and Development in 2016.

In common with the US strategy, these approaches are distinguished by their breadth and ambition. They endeavour to connect different maritime threats and risks, and aim to offer a comprehensive or holistic account of the challenges to be faced at sea. Thus the EU Maritime Security Strategy conceptualizes maritime security as 'a state of affairs of the global maritime domain, in which international law and national law are enforced, freedom of navigation is guaranteed and citizens, infrastructure, transport, the environment and marine resources are protected'21. Similarly, the UK National Strategy for Maritime Security is concerned with 'the advancement and protection of the UK's national interests, at home and abroad, through the active management of risks

${ }^{20}$ Hayne, Toward a new maritime strategy, 201.

${ }^{21}$ Council of the EU, European Union Maritime Security Strategy, (Brussels, 2014): 3. https://register.consilium.europa.eu/doc/srv?l=EN\&f=ST\%2011205\%202014\%20INI $\mathrm{T}$, 
and opportunities in and from the maritime domain, in order to strengthen and extend the UK's prosperity, security and resilience and to help shape a stable world'.22 Each of these maritime security strategies includes a different mix of emphases, inclusions and exclusions. The NATO strategy, for example, prioritizes deterrence and collective defence, alongside issues such as crisis management and cooperative security, and thus continues to emphasize 'hard' naval power alongside more diffuse maritime security tasks. ${ }^{23}$ The UK strategy, in contrast, explicitly does not consider 'defence of the realm', military campaigns or maritime safety as part of its remit. The AU's 2050 AIM Strategy emphasizes the importance of maritime resources and trade to economic security and development in the continent, with a focus on capacity-building in areas including coastguard capabilities and port facilities. ${ }^{24}$

Even so, the overall thrust of each of these approaches is essentially holistic, representing an attempt to understand and engage with the maritime arena as an interlinked security complex, rather than as a series of separate threats or challenges. They also recognize maritime security as a collective problem of political order, over which no one actor can exercise determinative control.

\section{The Core Dimensions of Maritime Security}

Seen in this way, the new strategic documents provide important considerations for security studies scholars concerning the nature of maritime security. Accordingly, the contemporary maritime security complex consists of four domains, each of which incorporates a series of variously cross-cutting security concerns.

22 HM Government, The UK National Strategy for Maritime Security, (London, 2014): 15, https://www.gov.uk/government/uploads/system/uploads/attachment_data/file/32 2813/20140623-40221_national-maritime-strat-Cm_8829_accessible.pdf, p. 15

${ }^{23}$ NATO, Alliance Maritime Strategy, (Brussels, 2011): 1, http://www.nato.int/cps/on/natohq/official texts 75615.html

${ }^{24} \mathrm{AU}, 2050$ Africa's Integrated Maritime Strategy, (2015): 8-10, http://cggrps.org/wp-content/uploads/2050-AIM-Strategy EN.pdf,. 
The first of these domains comprises what are best thought of as national security issues, corresponding largely to long-established traditions of naval strategy and sea power. The national security component of maritime security involves the development and application of naval power, incorporating military power projection and homeland defence at sea, as well as the use of warships to protect maritime trade routes and commerce through functions including deterrence, surveillance and interdiction. ${ }^{25}$ Such concerns remain of latent or extant importance in many parts of the world, most notably in regions of current geopolitical rivalry, such as the South China Sea.

A second domain addresses the marine environment. This incorporates a diverse range of issues such as marine pollution, vessel safety and regulation, maritime search and rescue, the state of ocean health, pollution and the impacts of climate change. The marine environment is a similarly long-established concern in the maritime sphere, with its genesis in international efforts to regulate shipping and other activities at sea through intergovernmental organizations such as the International Maritime Organization (IMO) or coordination bodies such as UN Oceans. Marine environment issues relate to maritime security in a number of ways. They represent a manifestation of wider environmental security concerns at sea and in coastal areas. They also concern the position of commercial shipping as a potential target for criminals, terrorists or pirates, and as a medium for trafficking in persons, illicit goods or weapons. ${ }^{26}$ Environmental degradation caused through fishery crimes or other environmental crimes, moreover, has the potential to increase the grievances of coastal populations and leads to maritime instability.

Marine environment issues are closely linked to a third domain of economic development. So-called 'blue economy' concerns underpin much of the maritime security agenda. Around 90 per cent of global trade travels by sea, and marine resources such as fisheries or offshore oil are key economic assets. ${ }^{27}$ Global commerce can be threatened by piracy, criminality or other forms of maritime disruption, while marine resource protection and development are often central priorities for

25 Christian Beuger, "What is maritime security?", Marine Policy, 53, (2015): 4

${ }^{26}$ Ibid. Bueger, (2015)

27 Opcit.HM Government (2014) 
coastal states. Indeed, it is notable in this regard that the AU's 2050 AIM Strategy places 'blue growth' at the heart of its narrative, while the EU produced its own specific 'blue growth' strategy in 2012.28

A final domain addresses issues of human security, in the sense of the insecurities experienced by individuals and local communities as well as those affecting states. ${ }^{29}$ Human security issues penetrate much of the maritime security agenda. The protection and sustainability of fisheries, for example, underpin the livelihoods of millions of people living in coastal regions, while these same groups are often the most vulnerable to the adverse impacts of climate change or maritime pollution. Such concerns relate not only to the security of the individuals and coastal communities themselves, but also to the role of human insecurity in facilitating the emergence of activities such as piracy or criminality as alternative sources of employment in regions of significant economic deprivation or breakdown.

Conceived of in this way, the maritime security agenda has four distinguishing characteristics. The first of these is the interconnected, sometimes interdependent, nature of the security challenges maritime security presents. ${ }^{30}$ For example, the collapse of the Somali state in the 1990s left coastal regions open to predation from illegal, unregulated or unreported fishing by richer states, as well as to other activities such as the unregulated disposal of toxic waste. Such activities exacerbated the already significant degradation of legitimate local fishing economies as a result of the war, and created a substantial body of socially and economically dislocated young men, whose primary 'saleable' skills were linked to seamanship through fishing or violence through

28 European Commissionm Blue growth: opportunities for marine and maritime sustainable growth, (Brussels, 2012), http://eur-lex.europa.eu/legalcontent/EN/TXT/PDF/?uri=CELEX:52012DC0494\&from=EN.

29 UNDP, Human Development Report 1994 (New York and Oxford: Oxford University Press, 1994), http://hdr.undp.org/sites/default/files/reports/ 255/hdr_1994_en_complete_nostats.pdf

${ }^{30}$ Speller, Understanding Naval Warfare. 
conflict. ${ }^{31}$ Piracy also appears to have been tolerated by local communities, owing to a strong defensive or moral narrative that portrayed it as a legitimate response to international predation. ${ }^{32}$ As a problematic of security, Somali piracy thus includes themes of national security (international naval patrols and engagements), maritime safety (safety and duty of care to hijacked ships' crews), economic development (fisheries protection and development) and human security (among vulnerable coastal communities). It is emblematic of the way in which many maritime security issues engender elements of both hard and soft power in relation to managing the consequences of insecurity and aspiring to address its root causes.

A second characteristic of maritime security is its liminality. Most maritime security issues are not simply to be-indeed, cannot simply be-understood and addressed as problems of the marine environment alone. Instead, they are invariably interlinked with challenges on land as well, as the case of Somali piracy discussed above illustrates. Land, costal zones, ports and other infrastructures are integral to maritime security in other ways too. The effective governance and security of port facilities are often key to managing such challenges as smuggling, robbery and corruption. Similarly, the 'back end' of piracy or terrorism - that is, the manner in which such activities are organized, sustained and funded, and the mechanisms through which profits are laundered and spentprimarily takes place on land. 33

Third, maritime security issues often transcend clear boundaries of governmental responsibility or state competence. The high seas are, by definition, a transnationalenvironment, over which sovereignty is shared, and where the state is but one actor among many. In this context, the management of maritime insecurity must inevitably incorporate a range of different actors and agendas, including those of the littoral states concerned, local communities and fishermen, flag states, multinational shipping or fishing interests, resource extraction and

${ }^{31}$ Abdi Ismail Samatar, Mark Lindberg, and Basil Mahayani, "The dialectics of piracy in Somalia: the rich versus the poor," Third World Quarterly 31, no. 8, (2010): 1377-94.

32 Ibid. Samatar, 2010.

${ }^{33}$ Justin Hastings, "Geographies of state failure and sophistication in maritime piracy hijackings", Political Geography, 28, no. 4, (2008): 215-16. 
tourism industries, and sometimes private security companies. ${ }^{34}$ So, for example, inter-national efforts to combat illegal, unregulated or unreported fishing or waste dumping at sea necessarily involve policing and enforcement actions by the navies or coastguards of individual states, regional cooperation and regulation of various sorts-including through international organizations such as the EU or UN-as well as engagement with the activities and practices of internationally diverse private actors or companies at sea. In this respect, as Till has observed, the 'battle for maritime security' is often a 'quintessentially cooperative' one. 35

Finally, and by extension, maritime security is inherently crossjurisdictional, or at least jurisdictionally complex. ${ }^{36}$ At an international level, piracy on the high seas has been tackled primarily as a problem of naval (law) enforcement, governed by international maritime law. Yet this raises a range of practical questions, such as how captured pirate suspects should be dealt with, including where they should be tried and potentially incarcerated. ${ }^{37}$ Even within territorial waters, there may be significant overlap or tensions between law enforcement, naval and development-driven security imperatives. Indeed, it is instructive in this regard to consider that the US NSMS replaced what had previously been a series of separate departmental-level strategies, including for example those of the Department of Defense and the Department of Homeland Security. ${ }^{38}$ The UK NSMS is even more jurisdictionally eclectic, making reference to at least 21 different government departments or agencies, including the Ministry of Defence, Foreign and Commonwealth Office,

34 Patrick Cullen, "Private security companies in the Malacca Straits: mapping new patterns of security governance", in Mercenaries, pirates, bandits and empires: private violence in historical context, ed. Alejandro Colas and Bryan Mabee, (London: Hurst, 2010): 187-212.

35 Geoffrey Till, (2016), "The Changing Dynamics of Seapower and Concepts of Battle”, in International order at Sea: How it is challenged. How it is maintained, ed. Bekkevold and Till, (Palgrave Macmillan UK, 2016)" p. 177.

${ }^{36}$ James, K., \& Raul, P. (2014).

37 Douglas Guilfoyle, "Counter-Piracy Law Enforcement and Human Rights", International and Comparative Law Quarterly 59, no.1, (2010): 141-69.

${ }^{38}$ US Government, The National Strategy, ii. 
Maritime and Coastguard Agency, Home Office, Department for Transport and Department for Environment, Food and Rural Affairs, among others. ${ }^{39}$

The maritime sphere is thus increasingly understood as a complex and holistic problematic of security, requiring extensive national, jurisdictional and public-private coordination if the challenges it presents are to be effectively addressed. In practice, these challenges of maritime insecurity are generating novel forms of association, integration and cooperation between actors. It is to these practices that this article now turns.

Many of our examples are drawn from the western Indian Ocean. This region incorporates a wide range of contemporary maritime security challenges, from piracy to geopolitical competition. It is of major global significance as a principal artery of maritime trade, and has also been a crucible of innovation in relation to the collective management of disorder. We do not suggest it presents a direct facsimile of practice and experience elsewhere. In other parts of the world-notably the South China Sea-different patterns may predominate. However, we do think that it is paradigmatic of changes and innovations that are of wider geographical relevance.

\section{Organizing Maritime Security and Managing Complexity}

When drafting its maritime security strategy, the EU conducted a mapping exercise of relevant agencies within the organization itself and its members. This exercise identified 383 groups or organizations that dealt with the issue in one way or another, reflecting the complexity of the maritime security environment at the European level alone. ${ }^{40}$ Similarly, the Contact Group on Piracy off the Coast of Somalia (CGPCS) faces the challenge of bringing together and coordinating the activity of over 80 states and 25 international organizations in order to address piracy in the western Indian Ocean. 41 The organizational and

${ }^{39}$ HM Government, The UK National Strategy for Maritime Security, 21.

40 Marcus Houben "The evolution of the EU's maritime security strategy", talk given at workshop on 'Building Trust to Enhance Maritime Security', (Coventry University, and the Small Arms Survey, Geneva, Switzerland, November 10 and 11, 2014).

41 Theirry Tardy, "Fighting piracy off the coast of Somalia: lessons learned from the Contact Group" in Paris: EU Institute for Security Studies, (2014). 
international diversity of such initiatives illustrates the challenge of producing coherent and holistic responses to the maritime security problematic.

In the western Indian Ocean region this challenge has led to a range of experiments in coordination and novel forms of association and practice within, among and between the various different actors involved in the maritime security complex. These innovations can be observed at three levels: first, an epistemic level centred on joint knowledge production; second, a coordination level focused on devising common scripts for action; and finally, an operational level incorporating joint maritime security activities in the field.

\section{Maritime Domain Awareness and New Epistemic Infra-structures}

At the epistemic level, innovation in the maritime security complex can be seen in a range of new mechanisms for knowledge production about the maritime security environment, and in particular the development of what are often called maritime domain awareness (MDA) or maritime situational awareness (MSA) initiatives. Such activities originate in efforts to improve mariners' awareness of current and impending weather conditions but, as Jeff Kline notes, increasingly provide 'an inspirational template for countering human-made threats to the maritime domain'.42 In order to do this, they draw on a wide range of data, including the (voluntary) tracking of ship movements through information-gathering systems such as the Automated Identification System (AIS); active surveillance through naval patrols, aerial reconnaissance, satellite imaging and radar systems; 43 and the collection and analysis of data from national and international agencies with a role in maritime security, including port authorities, customs and law enforcement. MDA aims to provide a rich database of information, often in real time, against which maritime security activities-including interceptions and inspections of vessels at sea-can be planned and targeted, through centralized data-mining techniques.

42 Jeff Kline, "Maritime security", in Securing freedom in the global common, ed., Scott Jasper (Stanford, CA: Stanford University Press, 2010 ): 69

${ }^{43}$ Laurent Etienne, Pelot Hjelmfet, Ronald Allen, and Melanie Fournier, "Global maritime situational awareness", in Global maritime security: new horizons, ed., Joseph S. Syliowicz and Ozlen Celebi, (Istanbul: Turkish Maritime Forces, 2014), 69-87 
The ambitions of MDA are considerable, and go well beyond marine surveillance as conventionally understood. ${ }^{44}$ Indeed, the US approach to MDA aims at nothing less than 'the effective understanding of anything associated with the maritime domain that could impact the security, safety, economy, or environment of the United States'. ${ }^{45}$ Such aspirations require significant transnational cooperation, as well as engagement with a wide range of substate and private actors. Other initiatives exploit the opportunities presented by communication and information technologies to open up new channels of knowledge exchange between civil and military actors, and between the navies or vessels of nations that might normally be reluctant to cooperate with each other. For example, international action against piracy off the coast of Somalia has been facilitated by the information-sharing platform Mercury, which allows various stakeholders-including national navies, international missions, and civil information-sharing centres-to communicate with each other through synchronous text-based chat, with a live feed on naval operations and piracy incidents providing real-time data to all participating actors. 46

\section{Coordination and Maritime Security Governance}

Similar innovations are taking place at the level of coordination and maritime security governance. Here, the maritime security agenda is giving rise to a number of new organizational mechanisms, the aim of which is to coordinate action in the face of shared challenges. Governance mechanisms such as the CGPCS are process-driven, informal organizations that work on principles of inclusivity rather than representation. They bring together a heterogeneous set of actors, including states, international organizations, industry associations, think-tanks, and civil and military representatives of implementing bodies in order to coordinate shared responses to maritime security

${ }^{44}$ Chris Rahman, "Maritime domain awareness: the key to maritime security", in Maritime security: international law and policy perspectives from Australia and New Zealand, ed., Natalie Klein, Joanna Mossop and David R. Rothwell, (Oxford: Routledge, 2010), 202.

45 US Government (2013), National maritime domain awareness plan (Washington DC, 2013): 1, https://www.hsdl.org/?abstract\&did=747691.

46 RowanWatt-Pringle, 'How to catch a pirate: technology is key', naval-technology.com, (2011), http://www.naval-technology.com/features/ featurehow-to-catch-a-piratecooperation-is-key/. 
challenges. Although the decisions of such organizations tend to be nonbinding in nature, they exert a substantial orchestrating effect and increasingly engender new forms of transnational coordination. The CGPCS, for example, has facilitated the development of a legal system on the basis of memorandums of understanding by which piracy suspects can be arrested, transferred, prosecuted and jailed across different jurisdictions. 47

In contrast to traditional regimes focused on rule enforcement, these organizations emphasize problem-solving and policy learning, and aim to develop new communities of inquiry among novel associations of actors, including many whose relations may under other circumstances be distant or even antagonistic. For instance, the Djibouti Code of Conduct brings together Arab states with partners from eastern and southern Africa to coordinate maritime security responses to piracy. ${ }^{48} \mathrm{~A}$ similar spirit is observable in many of the recent maritime security strategies discussed above. The EU strategy, for example, is not centred on creating new organizations and hierarchies to centralize the coordination of responses, but instead emphasizes a flexible and problem-orientated approach to shared challenges of maritime security governance. 49

\section{Operational Coordination}

These forms of association also find expression at the operational level, where, to date at least, they have been most prominent in antiterrorist and counter-piracy activities. Examples include NATO's Operation Active Endeavour (OAE), located in the Mediterranean, and the US-led Combined Maritime Forces (CMF), focusing on the western Indian Ocean. These operations were initially tasked with preventing the

47 Bueger, Christian "Experimenting with global governance: learning lessons in the Contact Group on Piracy", in Knowing governance: the epistemic construction of political order, ed, Jan-Peter Voss and Richard Freeman, eds, (Basingstoke: Palgrave Macmillan, 2015), 87-104.

48 Christian Bueger, and Mohanvir Singh Saran, "Finding a regional solution to piracy: is the Djibouti Process the answer?", Piracy-Studies.org, (August, 2012), http://piracystudies.org/2012/finding-a-regional-solution-to-piracy-is-the-djibouti-process-theanswer/

${ }^{49}$ Council of the EU, The European Union Maritime Security Strategy, 4-6 
proliferation of WMD and terrorist activities. However, since starting operations in 2002 they have considerably expanded their mandates and range of operations, which now include broader patrolling tasks, surveillance and interdiction. Both missions are characterized by a flexible participation structure. A range of non-NATO members have participated in OAE, for example, including Georgia, Russia and Ukraine. ${ }^{50}$ The CMF framework is even more inclusive, including a range of different non-NATO navies, some of which-including those of Pakistan, Japan and South Korea-have taken command responsibility for joint operations.

Another example is the Shared Awareness and Deconfliction Mechanism (SHADE), established in 2008 to conduct informal discussion among, and remove conflict from the activities of, the diverse nations and organizations involved in counter-piracy operations off the Horn of Africa. Since 2012, 14 international organizations and 33 countries have participated in SHADE meetings. 51 The novelty of the SHADE arrangement, and the opportunities it offers for addressing common problems, have been recognized by the US State Department, which described the organization as not ... a coalition [which] implies [centralized] command and control. Instead [there are] three organized missions and a wide variety of national independent deployers who have simply chosen to collaborate. No one is in charge. No one has command. They deconflict and operate constructively, and that's a new model of operation [...] many countries are voluntarily collaborating to secure the maritime space. That's a remarkable phenomenon. ${ }^{52}$

The shared challenges of the maritime security agenda are thus leading to practices that link information, actors and actions in ways that transcend established national or regional boundaries. They also bridge traditional civil-military and public-private distinctions, incorporating

50 NATO, Operation Active Endeavour (archived) (Brussels, 2016), http://www.nato.int/cps/en/natohq/topics 7932.htm

51 Jon Huggins and Jens Vestergaard Madsen, "The CGPCS: the evolution of multilateralism to multi-stakeholder collaboration", in Fighting piracy, p. 27; Oceans Beyond Piracy, Shared Awareness and Deconfliction (SHADE), ed., Thierry Tardy, p27, http://oceansbeyondpiracy.org/matrix/shared-awareness-and-deconflictionshade.

52 'Maritime TV panel discussion with Donna Hopkins, US State Department Coordinator on Counter Piracy and Maritime Security', Piracy Daily, (June 26, 2013). 
actors ranging from naval forces to shipping interests and private military security companies, who may be from otherwise antagonistic nations such as the United States, Iran, China and Russia. Such associations are circumstantially bounded, in the sense that they derive from specific coalitions of interest in the face of disorder at sea; in this case, the threat of piracy. However-in the western Indian Ocean region at least-it is striking that they have not dissolved with the decline of the piracy problem in the region since 2013. Indeed, there has been a gathering effort to institutionalize the priorities, infrastructures and practices of the maritime security agenda to the states of the region themselves through a process of capacity-building and devolved security governance.

Maritime security responses in the western Indian Ocean are reflected in analogues or emulations of core practices from the region in other parts of the world. For example, the G8++ Friends of the Gulf of Guinea Group is a security coordination mechanism modelled on the CGPCS. In the same region, the Djibouti Code of Conduct finds a parallel in the Yaounde Code of Conduct, adopted in 2013. The SHADE model has also been adopted elsewhere, for example in the creation of the so-called SHADE Med arrangement in 2015 to coordinate the actions of different actors and organizations in meeting the migration crisis in the Mediterranean. The Information Fusion Centre in Singapore hosts 'shared awareness meetings' which discuss maritime security issues and coordination in the south-east Asian region. MDA architectures are also increasingly common, including the US National Plan to Achieve Maritime Domain Awareness, the EU's Common Information Security Environment initiative and projects to develop MDA capacities in the Arctic. While not all such initiatives are as developed or successful as their counterparts in the western Indian Ocean, they are indicative of the increasing significance of such practices in maritime security governance more widely.

\section{Governing Maritime Security Abroad: Capacity-Building and SSR}

Another major type of international practice concerns attempts to distribute knowledge and skills for the management of maritime insecurity through initiatives in capacity-building and the reform of the maritime security sector. In the western Indian Ocean region there has been a significant growth in external initiatives since 2012. These were initially a response to Somali piracy, but since have taken a much wider 
focus, with activities aiming to address the root causes of maritime insecurity in the region, and to enable littoral states to take over key security governance tasks from the international community. SSR and capacity-building efforts in the maritime sphere are led by a number of core security actors. The key active states include the US and UK, alongside international and regional organizations such as the United Nations Office on Drugs and Crime, the EU and the IMO.

\section{Examples of US and EU Initiatives}

In December 2010 the US published a cross-departmental report on maritime security sector reform (MSSR), with the involvement of the Departments of State, Defense, Justice, Homeland Security and Transportation, and USAID.53 The report became an influential intellectual source and guidance document for how to organize a maritime security sector, and continues to be widely used in planning and implementation. The document adopts a holistic understanding of the maritime security concept, incorporating the challenges and institutions of maritime governance, maritime civil and criminal authority, maritime defence, maritime safety, maritime response and recovery, and maritime economy. ${ }^{54}$ It provides a comprehensive and systematic guide to MSSR in practice, with a range of technical assessment criteria, strategic guidelines and planning tools aimed at structuring and prioritizing MSSR activities across various actors and dimensions of maritime security governance. The activities themselves are likewise wide-ranging and comprehensive, ranging from initiatives aimed at strengthening maritime law enforcement, through training and capacity-building with local partners, to the development of countryspecific maritime law and policy, and the institutions of mechanisms for accountability and transparency in the maritime security sector. ${ }^{55}$

For its part, the EU has invested significant resources in maritime capacity-building initiatives, in what it self-consciously refers to as a 'comprehensive approach'.56 The EUCAP Nestor (from 2016, EUCAP

53 US Government, Maritime security sector reform (Washington DC, 2010), http://www.state.gov/documents/organization/154082.pdf.

54 Ibid

55 Ibid.

56 "Regional maritime security capacity building mission in the Horn of Africa and the western Indian Ocean", European Union External Action, (EEAS, Brussels, 2014): 2, 
Somalia) mission, for example, was established under the auspices of the EU's Common Defence and Security Policy, with the aim of enhancing the maritime capacities of Djibouti, Kenya, Tanzania, the Seychelles and Somalia. ${ }^{57}$ It has focused particularly on strengthening the rule of law in target countries and developing coastguard capacities through training and technical/material assistance. ${ }^{58}$ Other EU capacity-building initiatives include the Critical Maritime Routes programme, which develops regionally specific projects aimed at training, education and knowledge exchange in key areas of maritime insecurity; ${ }^{59}$ and the Maritime Security Programme (MASE), which incorporates social and development, legal, investigative, capacity-building, and regional coordination and information exchange components. 60

These US and EU programmes, as well as similar initiatives by other actors, ${ }^{61}$ share a number of characteristics. They draw on an understanding of maritime security that is multifaceted, involving capacity-building on land as well as enforcement at sea. A holistic approach is seen to be necessary because it encourages a focus on the commonalities of the problem or problems at hand, rather than on specific-and sometimes rather notional-institutional distinctions between, say, coastguard, navy and port police. It also recognizes the importance of wider governance issues in addressing the root causes of maritime insecurity. These activities thus make an explicit link between

http://www.eeas.europa.eu/csdp/missions-and-operations/eucapnestor/documents/factsheet_eucap_nestor en.pdf.

57 Ibid

58 EEAS(2012), European Union mission on regional maritime capacity building in the Horn of Africa (EUCAP NESTOR), Council decision 2012/389/CFSP, retrieved from http://eur-lex.europa.eu/legal-content/EN/TXT/PDF/?uri= CELEX:02012D0389$20151207 \&$ qid $=1473075547345 \&$ from $=$ EN.

${ }^{59}$ EU, Critical Maritime Routes Programme, https://criticalmaritime routes.eu/

${ }^{60}$ European Commission, Programme to promote regional maritime security (MASE, 2013), http://ec.europa.eu/europeaid/programme-promote-regional-maritimesecurity-mase_en.

61 Timothy Edmunds, "Maritime capacity building in the Horn of Africa: states of Somalia", EU-CIVCAP working paper, (2017): 3-5, https://eucivcap. files.wordpress.com/2017/06/eucivcap-workingpaper-01-17-edmunds.pdf. 
security, security institutions and the wider political and socio-economic environments in which they sit. They recognize that security responses do not exist in isolation from the wider polity in which they take place; they are nested within it, influenced by it, and themselves exert influence on it. 62

\section{Understanding Capacity-Building}

In one sense, this holistic approach is a straightforward instrumental reflection of and response to the institutional complexities and linkages inherent in the maritime security problematic. It represents an attempt to approach the building of maritime security in a joined-up way: to make connections where they exist and to avoid actions in one area that may be counterproductive in others. However, maritime capacitybuilding - like similar efforts on land63_also needs to be recognized as an explicitly normative endeavour. It is about how local actors can be supported and encouraged in managing their maritime security sectors in a particular manner and within a preferred model of political organization.

In application, it tends to give preference to the formal institutions of the state-the navy, police, coastguard and so on-as well as the legal frameworks within which they operate, and the bureaucratic and institutional mechanisms through which they are organized and administered. Where such institutions are weak or non-existent, it focuses on strengthening or rebuilding them through activities including training, resourcing and sometimes equipment or infrastructure provision.64 It is generally bound up with rationalist notions of organizational effectiveness, efficiency and planning. Thus, organizational reform often focuses on issues of professionalization in

62 Heiner Hänggi, (2004), "Conceptualising security sector reform and reconstruction”, in Reform and reconstruction of the security, , eds., Alan Bryden and Heiner Hänggi sector (New Brunswick, NJ, and London: Transaction), pp. 4-8

63 Mary Venner, (2015), 'The concept of "capacity" in development assistance: new paradigm or more of the same?', Global Change, Peace and Security 27, no. 1, (2015): 93-5.

${ }^{64}$ Mark Sedra (2010), 'Introduction: the future of security sector reform', The future of security sector reform, ed., Mark Sedra (Waterloo: Centre for International Governance Innovation, 2010), 7-23 
security institutions, including the definition of clear organizational roles and responsibilities, the development of appropriate structures, training and human resources to fulfil these tasks, the establishment of formal organizational planning models, and the implementation of common standards of best practice in their day-to-day operation. 65 It is also often distinguished by a focus on issues of good governance, accountability and transparency in the maritime security sphere-all of which are derived from notions of democratic politics.

Capacity-building thus aims to institutionalize externally derived notions of best practice in security governance, and to encourage local actors to share responsibility for the maritime insecurities in their own regions. However, it does face challenges. The normative nature of such activities may put them in tension with local priorities, interests or ways of doing things. ${ }^{66}$ For example, reforms aimed at strengthening and enforcing the fishing permit system in Somalia may run counter to the interests of those elites who benefit financially from its currently dysfunctional state. ${ }^{67}$ Efforts to eliminate petty corruption in the port police or coastguard may stumble in a fiscal environment in which serving personnel are rarely or inadequately paid. ${ }^{68}$

In order to address these tensions-and to increase the likelihood that reforms will become institutionalized and self-sustaining once external actors leave-capacity-builders often emphasize what is called 'local ownership' in their activities. Thus, for example, the EU's strategic framework for supporting SSR emphasizes 'the participation of all stakeholders' and the importance of 'inclusive consultation processes' as

65 Timothy Edmunds, Security sector reform in transforming societies: Croatia, Serbia and Montenegro (Manchester: Manchester University Press, 2007), 38-9

66 Timothy Edmunds, 'Illiberal resilience in Serbia', Journal of Democracy, 20 no. 1, (2009).

${ }^{67}$ Phillipe Leymarie, Philippe Rekacewicz, and Agnes Stienne, UNOSAT global report on maritime piracy: a geospatial analysis, 1995-2013 (Geneva: United Nations Institute for Training and Research, 2013), 21.

${ }^{68}$ Mark Downs, \& Robert Muggah, 'Breathing room: interim stabilization and security sector reform in the post-war period', in The future of security sector reform, Mark Sedra, ed., (2001), 140-44. 
baseline principles for its SSR initiatives. ${ }^{69}$ The same document notes that, to be 'applicable and effective', programmes should be 'developed on the basis of nationally owned processes', and that 'reform efforts will be effective and sustainable only if they are rooted in a country's institutions ... owned by national security and justice actors, and considered legitimate by society as a whole'.70 Similar aspirations are visible in the approaches of other actors, including the US government's MSSR framework.

In practice, the extent to which local ownership is taken seriously by external actors varies considerably. Often, it can be applied in a limited and even paradoxical manner, meaning the extent to which locals come to accept the (externally driven) security-building agenda on its own terms.71 At other times, it can be more nuanced and include the substantive engagement of local elites in the formulation, planning and evaluation of projects. Even so, notions of local ownership can expose important differences of priority between external donors and local actors. In Somalia, for example, local actors have tended to attach more importance to those aspects of the maritime capacity-building agenda associated with blue growth and human security, in contrast to many donors who stress anti-piracy or counter-terrorism activities.72Either way, the prevalence of local ownership discourse in these activities is indicative of the extent to which the maritime security agenda goes beyond a series of merely technical or instrumental responses to new security challenges. It also seeks to install and embed these responses in target regions, and to do so through mechanisms that strive to refashion and indigenize specific practices of governance in the recipient states concerned.

\section{The Future of Maritime Security Studies}

${ }^{69}$ European Commission , Elements for an EU-wide strategic framework to support security sector reform (2016), 5 , https://ec.europa.eu/europeaid/ sites/devco/files/joint-communication-ssr-20160705-p1-854572_en.pdf,

${ }^{70}$ Ibid

${ }^{71}$ Filip Ejdus, "Here is your mission: now please have some ownership": the rhetoric and practice of local ownership in CSDP operations', European Security, 26, no. 4, (2017).

${ }^{72}$ Edmunds, Maritime capacity building, 7. 
In 2017, around 80 per cent of the global population live within 160 kilometres of a sea coast, and many of the world's major citiesincluding, among many others, Lagos, London, Mumbai, New York, Shanghai and Tokyo-are situated in coastal locations. ${ }^{73}$ Rapid urbanization, particularly in the developing world, means that these numbers will rise significantly in the coming decades. The oceans also remain at the heart of global trade, with 90 per cent of all goods transported by sea, and the transport of maritime cargo expected to double between 2014 and $2020 .{ }^{74}$ The sea and its littoral are thus heavily implicated in the full range of contemporary security concerns, in ways and to an extent that are unlikely to diminish any time soon. In some parts of the world-the South China Sea, for example-such concerns may be obscured or overshadowed by geopolitical competition and naval confrontation. ${ }^{75}$ However, even under these circumstances, the challenges of the maritime security agenda remain present, as do significant areas of shared interest in relation to, for example, environmental protection or the free passage of commercial vessels. ${ }^{76}$

In contrast to some observers, who argue that we are entering a new period of danger, even anarchy, 77 we suggest that the maritime security agenda is in fact leading to new forms of international order at sea. This process is pragmatic and incremental in nature, driven by innovation and change in the maritime arena itself rather than by wider structural shifts in geopolitics or international regulation. International actors are developing practical responses to the specific challenges of maritime security. These reflect the requirement to coordinate and integrate the four domains of maritime security-namely sea power, the marine environment, economic development and human security. Such

${ }^{73}$ NATO, Alliance Maritime Strategy, para.II.4.

${ }^{74}$ HM Government, The UK National Strategy, 39.

75 Zhou Fangyin, "Between assertiveness and self-restraint: understanding China's South China Sea policy," International Affairs, 92, no. 4, (2016).

76 Patalano, Alessio, "Maritime strategy and the South China Sea", in Maritime strategy and Global Order: Market, Resource, Security, eds., Daniel Moran, James A. Russell, (Georgetown University Press, 2016), 121, 143.

77 Dave Sloggett, The anarchic sea: maritime security in the twenty-first century (London: Hurst, 2013). 
responses have occurred at the epistemic, coordination and operational levels, and have been exported through capacity-building projects.

\section{The Future Agenda of Maritime Security Studies}

Understanding maritime security and the structural and practical challenges it poses for how the sea is governed will require ongoing indepth studies of the activities and initiatives that international actors undertake to cope with the key elements of maritime security. This implies expanding the view beyond the perspective of traditional realist and liberal theorizing and using the more fine-grained lenses provided by new security studies in considering normative structures, practices and knowledge. It is necessary, while retaining the insights of studies of sea power and maritime law, to take them further by connecting them to more sociological and more empirical interdisciplinary observations.

Five areas in particular require further attention. First, we need to understand the changing character of sea power and the way it is being transformed through connections with concerns over the marine environment, the blue economy and human security, the new emphasis placed on maritime crime and law enforcement at sea, and the full range of practical innovations in use, including technology and informal practices. Second, we need to revisit the role of formal and informal rules for maritime security governance and examine how these are enforced through operations at sea, new (informal) legal coordination mechanisms and capacity-building, considering the creativity required to manage the complexity and increasing fragmentation of maritime law. Third, we need to analyse the ways in which established patterns of international security cooperation-alliances, multinational operations and so on-have become more diffuse, complex and associational, involving a range of (often otherwise antagonistic) national partners, but also private and other non-state actors, including shipping companies, private military and security companies, fishing communities and other sub-state groups. These activities expand and challenge many traditional notions of state action and cooperation, and suggest a range of novel mechanisms and networks through which security can-and is-being practised. Fourth, we need to pay more attention to the connections between land and sea, the different forms of maritime crime and other threats, and how these reinforce each other. If these issues are to be understood and ameliorated, maritime security studies needs to incorporate a more sustained engagement with their causes and interactions on land, as well as their manifestations at sea. Fifth, we need 
to revisit the political functions and structural effects of capacitybuilding in the maritime sphere. At present, these initiatives remain relatively immature compared to their more established counterparts on land, and there is much that may be gained from a more systematic sharing of experience. This is particularly so with regard to the manner in which such efforts are received in the target communities in which they take place, including the question of local ownership, and has implications for their efficacy and sustainability over the long term.

In short, we believe that it is time for security studies to move beyond seablindness and recognize the maritime arena as a crucible for change and innovation in global politics as a whole. Doing so will lead to a more interconnected and broadly relevant understanding of the maritime security complex, and will open up an important area of international interaction to the discipline more widely. 